Key Words:

DWPF, SRAT

CPC, reductant

Retention:

Permanent

\title{
SELECTION AND PRELIMINARY EVALUATION OF ALTERNATIVE REDUCTANTS FOR SRAT PROCESSING
}

\author{
B. R. Pickenheim \\ M. E. Stone \\ D. K. Peeler
}

JUNE 2009

Savannah River National Laboratory

Savannah River Nuclear Solutions

Aiken, SC 29808

Prepared for the U.S. Department of Energy Under Contract Number DE-AC09-08SR22470

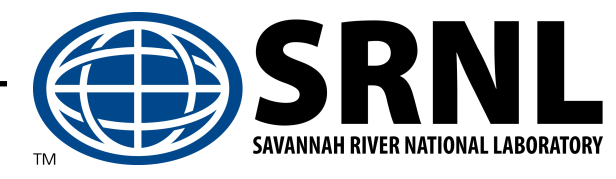




\section{DISCLAIMER}

This work was prepared under an agreement with and funded by the U.S. Government. Neither the U. S. Government or its employees, nor any of its contractors, subcontractors or their employees, makes any express or implied:

1. warranty or assumes any legal liability for the accuracy, completeness, or for the use or results of such use of any information, product, or process disclosed; or

2. representation that such use or results of such use would not infringe privately owned rights; or

3. endorsement or recommendation of any specifically identified commercial product, process, or service.

Any views and opinions of authors expressed in this work do not necessarily state or reflect those of the United States Government, or its contractors, or subcontractors.

Printed in the United States of America

Prepared for

U.S. Department of Energy 
Key Words:

DWPF, SRAT

CPC, reductant

Retention:

Permanent

\section{SELECTION AND PRELIMINARY EVALUATION OF ALTERNATIVE REDUCTANTS FOR SRAT PROCESSING}

B. R. Pickenheim

M. E. Stone

D. K. Peeler

JUNE 2009

Savannah River National Laboratory

Savannah River Nuclear Solutions

Savannah River Site

Aiken, SC 29808 
SRNL-STI-2009-00120, REVISION 0

\section{REVIEWS AND APPROVALS}

B. R. Pickenheim, Environmental and Chemical Processing Technology

Date

M. E. Stone, Environmental and Chemical Processing Technology

Date

D. K. Peeler, Environmental and Chemical Processing Technology

Date

D. P. Lambert, Peer Reviewer,

Date

Environmental and Chemical Processing Technology

C. C. Herman, Process Technology Programs Manager

Date Environmental and Chemical Processing Technology

S. L. Marra, Manager

Date

Environmental and Chemical Processing Technology Research Programs

J. E. Occhipinti, Manager,

Date

Waste Solidification Engineering

- ii - 


\section{TABLE OF CONTENTS}

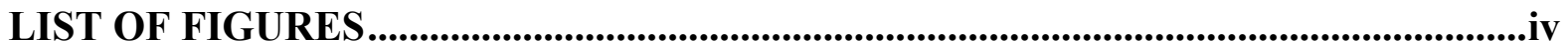

LIST OF TABLES............................................................................................................................iv

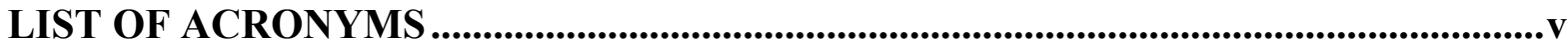

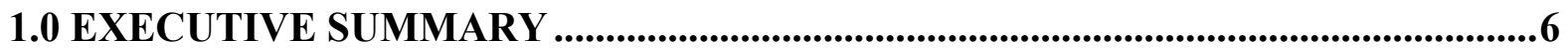

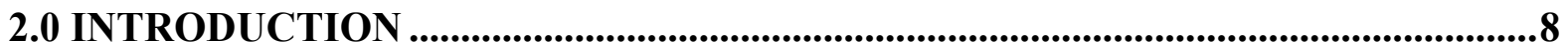

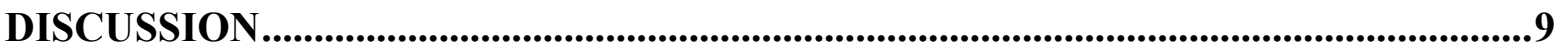

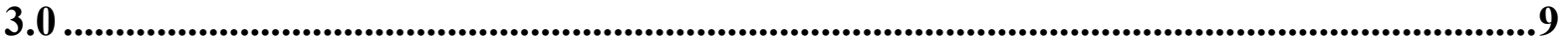

3.1 Alternative Reductant Candidate Selection......................................................................9

3.1.1 Acidic Reductant Selection ..........................................................................12

3.1.2 Non-Acidic Reductant Selection ...............................................................................13

3.1.3 Selection of Reducing Agents for Testing .......................................................................16

3.2 Evaluation of Candidates...................................................................................................16

3.2.1 Supernatant Testing .........................................................................................................16

3.2.2 High Throughput SRAT Testing............................................................................19

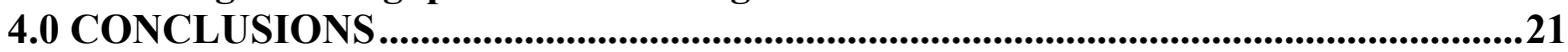

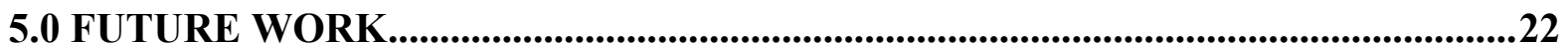

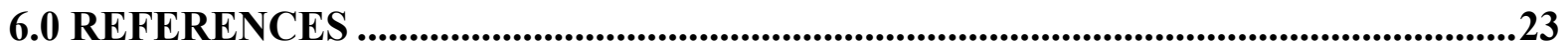

APPENDIX A. Options for Elimination of Formic Acid .......................................................25 


\section{LIST OF FIGURES}

Figure 1. REDOX of INL SBW as a Function of Sugar Addition .14

\section{LIST OF TABLES}

Table 1. Acidic Reductant Selection Matrix .................................................................... 9

Table 2. Non-Acidic Reductant Selection Matrix ........................................................ 10

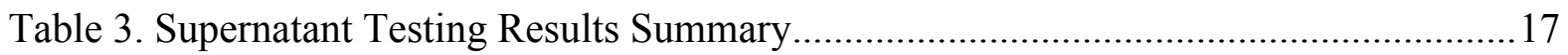

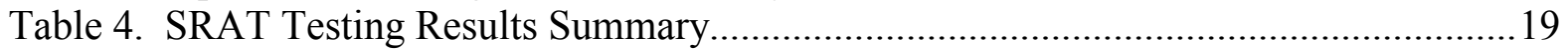

Table A- 1. Ranking of Alternative Reductant Options .......................................................26 


\section{LIST OF ACRONYMS}

$\begin{array}{ll}\text { CCIM } & \text { Cold Crucible Induction-heated Melter } \\ \text { CPC } & \text { Chemical Process Cell } \\ \text { DWPF } & \text { Defense Waste Processing Facility } \\ \text { HLW } & \text { High Level Waste } \\ \text { INL } & \text { Idaho National Laboratory } \\ \text { PNNL } & \text { Pacific Northwest National Laboratory } \\ \text { REDOX } & \text { REDuction OXidation potential } \\ \text { SB } & \text { Sludge Batch } \\ \text { SBW } & \text { Sodium Bearing Waste } \\ \text { SME } & \text { Slurry Mix Evaporator } \\ \text { SRAT } & \text { Sludge Receipt and Adjustment Tank } \\ \text { SRNL } & \text { Savannah River National Laboratory } \\ \text { VSL } & \text { Vitreous State Laboratory }\end{array}$




\subsection{EXECUTIVE SUMMARY}

Defense Waste Processing Facility - Engineering (DWPF-E) has requested the Savannah River National Laboratory (SRNL) to perform scoping evaluations of alternative flowsheets with the primary focus on alternatives to formic acid during Chemical Process Cell (CPC) processing.

The reductants shown below were selected for testing during the evaluation of alternative reductants for Sludge Receipt and Adjustment Tank (SRAT) processing. The reductants fall into two general categories: reducing acids and non-acidic reducing agents. Reducing acids were selected as direct replacements for formic acid to reduce mercury in the SRAT, to acidify the sludge, and to balance the melter REDuction/OXidation potential (REDOX). Non-acidic reductants were selected as melter reductants and would not be able to reduce mercury in the SRAT. Sugar was not tested during this scoping evaluation as previous work has already been conducted on the use of sugar with DWPF feeds.

\section{Reducing Acids \\ $>$ Glycolic acid \\ $>$ Pyruvic acid \\ $>$ Malonic acid \\ $>$ Citric acid \\ $>$ Acrylic acid \\ $>$ Oxalic acid \\ $>$ Proprionic acid \\ Non-acid Reducing Agents \\ $>$ Tin chloride \\ $>$ Silicon monoxide \\ $>747$ Antifoam \\ $>$ Dolapix CE64 \\ $>$ Disperse-Ayd W28}

Based on the testing performed, the only viable short-term path to mitigating hydrogen generation in the CPC is replacement of formic acid with a mixture of glycolic and formic acids. An experiment using glycolic acid blended with formic on an 80:20 molar basis was able to reduce mercury, while also targeting a predicted REDuction/OXidation (REDOX) of 0.2 expressed as $\mathrm{Fe}^{2+} / \Sigma \mathrm{Fe}$. Based on this result, SRNL recommends performing a complete CPC demonstration of the glycolic/formic acid flowsheet followed by a design basis development and documentation. Of the options tested recently and in the past, nitric/glycolic/formic blended acids has the potential for near term implementation in the existing $\mathrm{CPC}$ equipment providing rapid throughput improvement.

Use of a non-acidic reductant is recommended only if the processing constraints to remove mercury and acidify the sludge acidification are eliminated. The non-acidic 
SRNL-STI-2009-00120, REVISION 0

reductants (e.g. sugar) will not reduce mercury during CPC processing and sludge acidification would require large amounts of nitric acid (and subsequently larger reductant additions) unless a reducing acid is also used. 


\subsection{INTRODUCTION}

DWPF-E has requested SRNL to perform scoping evaluations of alternatives to the current CPC flowsheet with particular emphasis on replacing formic acid during DWPF processing [Pickenheim, 2008]. Formic acid is used during the DWPF process to accomplish a number of different processing objectives: acidify the sludge, reduce mercury during the SRAT cycle, and control melter REDuction/OXidation potential (REDOX). The need for each of these processing objectives for formic acid was identified during initial development of the DWPF flowsheet.

The sludge received from the tank farm contains high concentrations of sodium hydroxide and sodium carbonate with a resulting $\mathrm{pH}$ greater than 13. Initial flowsheet testing for the DWPF process with this sludge identified issues with the yield stress of the melter feed at the desired solids concentration. Acid was added to the flowsheet to meet the required rheological properties of the melter feed. Concurrently, a need to remove mercury from the sludge during pretreatment was identified. Acidification of the sludge using formic acid allowed mercury to be reduced and implementation of steam stripping allowed the reduced mercury to be removed. Removal of mercury during CPC processing eliminates the potential for excessive deposition of mercury compounds in the melter offgas system. Initial melter testing identified a need to control the REDOX potential in the melter to control foaming and prevent formation of metallic species. A blend of nitric acid and formic acid to acidify the sludge was found to produce the needed glass REDOX.

Although the current nitric/formic acid flowsheet has successfully been implemented for sludge batches 1 through 5 in DWPF, the SRAT process is time intensive and with improved efficiencies in melter processing may become the rate limiting step. Hydrogen generation from the degradation of formic acid by the noble metals present in the sludge requires extensive testing prior to each sludge batch as well as constant monitoring of the hydrogen content of the SRAT and SME offgas system. It also presents a challenge for coupled operations due to the need to evaporate the large volume of salt processing streams for extended time periods. The flowsheet has also limited the ability to introduce new streams that are high in nitrate because of the need for REDOX balance with formic acid. Therefore, SRNL was tasked to investigate alternative flowsheets that may help address these concerns as well as alleviate some of the concerns with the processing and storage of formic acid.

Options for elimination of formic acid from the DWPF process include removal of sludge acidification from the DWPF flowsheet, replacement of formic acid with another acid to adjust rheology, replacement of formic with a reducing acid for REDOX control, and replacement of formic acid with a reducing acid that reduces mercury during the SRAT cycle. Options for minimizing the amount of formic acid utilize an alternative reductant for melter REDOX, but retain formic acid for mercury reduction. The impact on the DWPF flowsheet is significantly different for each of the options identified, as discussed in Section 3. 


\subsection{DISCUSSION}

\subsection{ALTERNATIVE REDUCTANT CANDIDATE SELECTION}

A list of processing objectives for the alternative reductant was developed to aid in the selection of candidates for testing. In addition, the selection process considered factors such as prior use in melter systems. The objectives were:

1. Eliminate/minimize storage and handling hazards of formic acid

2. Eliminate/minimize hydrogen generation (ie. eliminate gas chromatograph requirements)

3. Maintain control of foaming in melter

4. Maintain feed processability

a. Acceptable/improved SME product yield stress

b. No/minimal sulfur (or other species harmful to melter) additions

c. No/minimal additional degradation products in condensates

d. No residue buildup in vessels/lines

e. No foaming from additives

5. Continue to remove mercury from melter feed

6. Maximize ability to process nitrate from other SRS streams

Different options exist for accomplishing all or part of the desired objectives. Appendix A describes and ranks these options.

The list of potential candidates identified is shown in Table 1 and Table 2. These candidates were identified by a literature review of available reducing agents and from other research programs. For example, the rheological modification agents identified during DWPF research programs were evaluated to determine their potential to act as an effective reductant.

Some generic issues exist with many of the reductants identified during the testing. Most of the reductants selected would require analytical method development prior to implementation if analytical verification of the amount of reductant is required. If the reductant is added during the SRAT or SME cycle, then reductant stability during boiling and in radiation fields would have to be demonstrated. Even if the addition is made at the end of the SME cycle, the 1500 gallon (or larger) heel maintained in the SME vessel allows the exposure of a large fraction of the additive to the concentration steps in the next SME cycle. The offgas condensate composition and offgas emissions may be changed by degradation products from the alternative reductant. Finally, issues with the ability to control melter REDOX between 0.1 and $0.33 \mathrm{Fe}^{+2} / \Sigma \mathrm{Fe}$ are known with some reductants (such as sugar - see Section 3.2.2.2 for more details). 
Table 1. Acidic Reductant Selection Matrix

\begin{tabular}{|c|c|c|c|c|c|}
\hline Reductant & Formula & $\begin{array}{l}\text { Acid } \\
\text { pKa }\end{array}$ & & $\begin{array}{c}\text { Carbon / } \\
\text { Cation } \\
\text { Oxidation } \\
\text { State } \\
\end{array}$ & Structure \\
\hline & & 1 & 2 & & \\
\hline Formic Acid & $\mathrm{CH} 2 \mathrm{O} 2$ & 3.751 & & 2 & $\mathrm{H}$ \\
\hline Oxalic Acid & $\mathrm{C} 2 \mathrm{H} 2 \mathrm{O} 4$ & 1.271 & 4.272 & 3 & \\
\hline Propionic Acid & $\mathrm{C} 3 \mathrm{H} 6 \mathrm{O} 2$ & 4.874 & & -0.667 & \\
\hline Malic Acid & $\mathrm{C} 4 \mathrm{H} 6 \mathrm{O} 5$ & 3.4 & 5.13 & 1 & \\
\hline Maleic Acid & $\mathrm{C} 4 \mathrm{H} 4 \mathrm{O} 4$ & 1.94 & 6.33 & 1 & \\
\hline Malonic Acid & $\mathrm{C} 3 \mathrm{H} 4 \mathrm{O} 4$ & 2.826 & 5.696 & 1.33 & $\mathrm{H}$ \\
\hline Glycolic Acid & $\mathrm{C} 2 \mathrm{H} 4 \mathrm{O} 3$ & 3.831 & & 1 & \\
\hline Acrylic acid & $\mathrm{C} 3 \mathrm{H} 4 \mathrm{O} 2$ & 4.26 & & 0 & \\
\hline Ascorbic Acid & $\mathrm{C} 6 \mathrm{H} 8 \mathrm{O} 6$ & 4.17 & 11.6 & & \\
\hline Citric Acid & $\mathrm{C} 6 \mathrm{H} 8 \mathrm{O} 7$ & 3.128 & 4.761 & 1 & \\
\hline Succinic Acid & $\mathrm{C} 4 \mathrm{H} 6 \mathrm{O} 4$ & 4.207 & 5.635 & 0.5 & \\
\hline Pyruvic acid & $\mathrm{C} 3 \mathrm{H} 4 \mathrm{O} 3$ & 2.49 & & 0.67 & \\
\hline EDTA & $\mathrm{C} 10 \mathrm{H} 16 \mathrm{~N} 2 \mathrm{O} 8$ & 0.0 & 1.5 & 1 & \\
\hline
\end{tabular}


SRNL-STI-2009-00120, REVISION 0

Table 2. Non-Acidic Reductant Selection Matrix

\begin{tabular}{|c|c|c|c|}
\hline Reductant & Formula & $\begin{array}{l}\text { Carbon / } \\
\text { Cation } \\
\text { Oxidation } \\
\text { State }\end{array}$ & Structure \\
\hline Antifoam 747 & & $\begin{array}{c}\text { Not } \\
\text { determined }\end{array}$ & Siloxane based \\
\hline Dolapix CE64 & & $\begin{array}{c}\text { Not } \\
\text { determined }\end{array}$ & glycol based \\
\hline Disperse-Ayd W-28 & & $\begin{array}{c}\text { Not } \\
\text { determined }\end{array}$ & Polyacrylate based \\
\hline $\begin{array}{l}\text { HPMA (Hydrolyzed } \\
\text { PolyMaleic Anhydride }\end{array}$ & MW: $400-800$ & 1 & 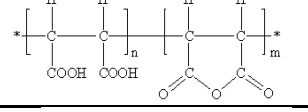 \\
\hline Sugar(sucrose) & $\mathrm{C} 12 \mathrm{H} 22 \mathrm{O} 11$ & 0 & 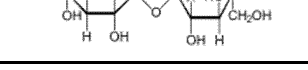 \\
\hline Silicon Monoxide & $\mathrm{SiO}$ & 2 & \\
\hline Tin chloride & $\mathrm{SnCl} 2$ & 2 & \\
\hline
\end{tabular}




\subsubsection{Acidic Reductant Selection}

A long list of potential acids was available for consideration. A previous study by Pacific Northwest National Laboratory (PNNL) evaluated some of the candidates and selected glycolic acid as the most suitable replacement for formic acid [Seymour, 1995], but mercury reduction was not considered during that study. Desired characteristics of the replacement acid were: 1) previous use in glass redox control, 2) commercial availability, 3) concentration available, 4) acid pKa, and 5) currently used in SRS High Level Waste (HLW) systems.

Most of the acids selected were small chain length carboxylic acids of various forms (formic acid is also a carboxylic acid).

\subsubsection{Glycolic Acid}

Glycolic acid has been utilized and shown to be effective as a reductant in waste glass REDOX control. Small scale melter tests have been conducted using glycolic acid as a replacement for sugar. Glycolic acid has a $\mathrm{pKa}$ similar to formic acid and is commercially available at concentrations up to $80 \mathrm{wt} \%$. Trace amounts of hydrogen were noted during a pretreatment test with glycolic acid during the PNNL study [Seymour, 1995], but the quantities were $1 / 100^{\text {th }}$ the amount seen with formic acid. Complete elimination of hydrogen evolution is not possible as radiolytic hydrogen will occur regardless of reductant chosen; therefore glycolic was not eliminated from consideration.

\subsubsection{Malonic Acid, Pyruvic Acid, Proprionic Acid}

These three acids were selected as alternate carboxylic acids to be tested along with glycolic acid and oxalic acid, primarily to determine if any of these acids would reduce mercury. Glycolic acid has been tested in HLW systems and is the preferred candidate, but the ability to reduce mercury has not been demonstrated with glycolic acid. Therefore, these alternatives were selected to test their mercury reduction capacity.

\subsubsection{Citric Acid}

Citric acid has been used as a rheological modifier for high level waste. It is the longest chain acid selected for testing.

\subsubsection{Oxalic Acid}

Oxalate is currently present in HLW tanks and is currently in use for various cleaning processes. The main drawback to oxalic acid is the limited solubility and potential reactions with mercury species to form mercuric oxalate (an explosive compound).

\subsubsection{Acrylic Acid}


Acrylic acid was selected for testing to provide more variety in the types of acids tested. It is the only acid tested that contains a carbon-carbon double bond. The primary drawback to acrylic acid is the potential for polymerization in the storage tank, requiring controls to be in place to allow safe storage.

\subsubsection{Non-Acidic Reductant Selection}

The candidate list for non-acidic reductants was selected from known reductants (sugar, SiO, $\mathrm{SnCl}$ ), reductants already added to the process for other reasons in small amounts (747 antifoam), and potential additives to control melter feed yield stress (Dolpix CE-64 and Disperse-Ayd W28). Of these reductants, only $\mathrm{SnCl}$ is expected to be able to reduce mercury during the CPC process. As discussed in the options rankings, use of a non-acidic reductant is recommended only if elimination of mercury removal and sludge acidification is implemented.

\subsubsection{Tin Chloride}

Tin chloride is a powerful reducing agent and the only acceptable non-acidic reducing agent identified that had the potential to reduce mercury in the CPC process. The addition of chloride to the system is the primary drawback since it has limited solubility in glass and can be corrosive to the melter and offgas system.

\subsubsection{Sugar}

Studies have previously been conducted using sugar as melter reductants for the DWPF process and it has been utilized in other vitrification programs. Feasibility studies with sugar were deemed unnecessary at this stage of the program as the previous studies have already shown that sugar is effective as a reductant for the DWPF melter. Although sugar has been proven as a reductant for HLW vitrification, several issues with implementation at DWPF exist in addition to the generic issues listed above (analytical method and exposure to the boiling process).

Tests were conducted with sugar during the melt rate improvement testing for Sludge Batch $1 \mathrm{~b}$ (SB1b) [Stone, 2000] and again during SB2 melt rate testing [Josephs, 2001]. The sugar was added to dry feed material during the SB1b (MB2) testing. Issues were noted with the ability to predict the REDOX of glass made with sugar reductants due to the shape of the curve of REDOX versus sugar addition amount (discussed below, similar to the $\mathrm{pH}$ response during acid-base neutralization). The SB2 tests with sugar added the sugar as an additional reducing agent to SRAT product that had undergone the typical CPC process (balanced nitric and formic acid). The sugar was added to the feed slurry prior to drying the melter feed and resulted in an increased volume expansion during melting and a decrease in melt rate. Large volume expansions were also noted during crucible studies conducted by PNNL [Smith, 1995]. 
The profile of REDOX with sugar addition is clearly illustrated in data obtained from testing with Sodium Bearing Waste (SBW) from Idaho National Laboratory (INL) as shown in Figure 1 [Perry, 2001]. Accurately controlling the REDOX to a target between 0.1 and 0.33 is difficult in this type of system as small errors in measurement of nitrate concentration, feed volume, or addition amount could lead to significant changes in melter REDOX. Although this issue may be present for other reductants, this behavior is known for sugar and represents a significant issue to the implementation of sugar.

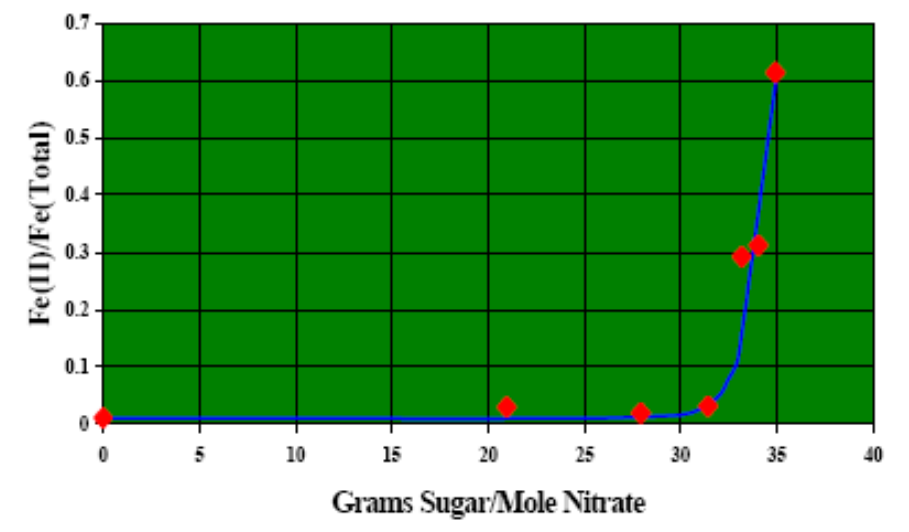

Figure 1. REDOX of INL SBW as a Function of Sugar Addition

Sugar is known to increase yield stress in some systems and could lead to difficulty pumping the melter feed and hinder the spreading of the cold cap. Tests with DWPF feed were conducted during the rheological modifier program using sugar as an additive [Marinik, 2004]. No significant change to the yield stress was noted, but the consistency of the feed did increase slightly.

Although sugar was used for REDOX control during the vitrification of high-level waste at West Valley Demonstration Project (WVDP) and is currently planned for use in the Waste Treatment Plant (WTP) at Hanford, the use of sugar does have potential negative impacts to melter processing if not well understood, controlled, and/or the specific melter configuration is not capable of handling the potential negative impacts. More specifically, oxidizing melts can lead to foam formation which can have a negative impacts on melt rate. Reducing melts can lead to precipitation of metals within the melt pool that have the propensity to settle in the melter which can lead to electrical short circuits for Joule Heated melters and reduced melter life expectancies. For these reasons, DWPF targets a REDOX $\left(\mathrm{Fe}^{2+} / \mathrm{Fe}_{\text {total }}\right)$ of 0.2 to mitigate these potential processing issues [DPSTD-80-38-2].

Perry et al. (2001) used sugar as a REDOX control for vitrification of INL sodium-bearing waste (a highly acidic salt solution $\left(\sim 1 \mathrm{M} \mathrm{H}^{+}\right)$containing high concentrations of nitrate 4.82 $\mathrm{M}$ - highly oxidizing). Although sugar would be useful in denitrating the feed during melter processing, the maximum reductant concentration that could be effectively used is often limited by the oxidation state of the glass product. Excess reductant will tend to reduce not only nitrates but glass oxides. Prior to melter testing, slurry-fed laboratory testing was preformed to determine the amount of sugar to be used to target a specific REDOX. Figure 1 summarizes the results of the laboratory data. Perry et al. (2001) noted that a $\mathrm{Fe}^{2+} / \mathrm{Fe}_{\text {total }}$ ratio 
of $0.2-0.3$ was desired and based on the laboratory scale data, sugar was added to the feed slurry at 160 grams per liter, equivalent to a sugar to nitrate ratio of 31 grams of sugar per mole nitrate.

Interestingly, based on the laboratory data (shown in Figure 1), 31 grams of sugar per mole nitrate would target a REDOX of $<0.1$. The slope of the REDOX vs sugar/mole nitrate curve apparently encouraged the use of 31 grams of sugar to avoid overly reducing the glass melt pool. That is, based on the laboratory scale data, there is a relatively small "window" with respect to the amount of sugar that could be used leading to REDOX values ranging from 0.1 to $0.6 \mathrm{Fe}^{+2} / \Sigma \mathrm{Fe}$. The authors elected to use less sugar than that required to target a $0.2 \mathrm{Fe}^{+2} / \Sigma \mathrm{Fe} \mathrm{REDOX}$ in this situation.

Based on the use of 31 grams of sugar per mole nitrate, the REDOX of the glass from the melter runs averaged (an approximate steady-state average) 0.14 - greater than the projected REDOX from the laboratory data. During post inspection of the molybdenum electrodes and drain, significant oxidation was noted and attributed to "oxidizing" nature of the feed or glass. Although molybdenum based materials are not part of the current DWPF melter configuration (oxidation of materials of construction may not be an issue at present), the potential for overly oxidizing conditions need to be evaluated with respect to possible foam formation (i.e., formic used in the DWPF baseline process to reduce the Mn to avoid excessive liberation of oxygen within the melt pool). MnO contents of the SBW-9 glass were approximately $0.25 \mathrm{wt} \%$ as compared to MnO contents in DWPF glasses that could be as high as 4 or $5 \mathrm{wt} \%$ in glass depending on the sludge type and waste loading target. During the SBW-9 melter test, the edges of the liquid feed pool appeared "foamy but the feed that flowed to the edges of the pool rapidly digested into the melt" Future descriptions of the foam layer indicated that the "foam that appears at these edges was soft and flowed easily". Again, the potential differences in $\mathrm{MnO}$ content of the SBW feed as compared to typical DWPF MnO concentration may have suppressed the thermal reduction of $\mathrm{MnO}$ leading to foam formation.

\subsubsection{Silicon Monoxide}

Melt rate testing has considered the use of a "two-component" frit that removes a portion of the silica from the frit and utilizes a separate addition of silica to the SME process. The twocomponent frit improved melt rate, but not enough to justify the required changes to implement the two component process. Use of $\mathrm{SiO}$ could allow the separate addition to accomplish several objectives: increased melt rate by allowing a less refractory frit to be used, minimize amount of organics in the melter feed, and control melter redox.

\subsubsection{747 Antifoam}

The 747 antifoam is currently added to both the SRAT and SME processes and is known to act as a reducing agent based on previous testing. Several issues with implementation exist: 1) Cost - the antifoam would be the most expensive agent to purchase 2) Offgas/Condensate Issues - antifoam degradation products are known to partition to the offgas/condensate 
system during CPC processing. The addition of much larger amounts of antifoam could lead to issues with organic levels in the condensate and/or excessive buildup in the offgas lines 3) Analytical Method - Measurement of the amount of antifoam in the SME product would require method development. Another issue with the use of antifoam is the amount of silicon that partions to the offgas condensate from degradation of the antifoam during processing.

\subsubsection{Dolapix CE-64 and Disperse-Ayd W28}

The rheological modifier program has identified these two surfactants as effective yield stress reducing agents for the DWPF melter feed, with concentrations as high as 10,000 ppm utilized during the test program [Marinik, 2004]. If these agents act as reducing agents, then they could perform two roles as surfactant to reduce yield stress and as a redox control agent.

\subsubsection{Selection of Reducing Agents for Testing}

The reductants shown below were selected for testing during the evaluation of alternative reductants for SRAT processing. The reductants fall into two general categories: reducing acids and non-acidic reducing agents. Reducing acids were selected as direct replacements for formic acid to reduce mercury in the SRAT, to acidify the sludge, and to balance the melter REDOX. Non-acidic reductants were selected as melter reductants and would not be able to reduce mercury in the SRAT. Sugar was not tested during this scoping evaluation as previous work has already been conducted on the use of sugar with DWPF feeds.

$$
\begin{aligned}
& \text { Reducing Acids } \\
& >\text { Glycolic acid } \\
& >\text { Pyruvic acid } \\
& >\text { Malonic acid } \\
& >\text { Citric acid } \\
& >\text { Acrylic acid } \\
& >\text { Oxalic acid } \\
& >\text { Proprionic acid }
\end{aligned}
$$

Non-acid Reducing Agents

$>$ Tin chloride

$>$ Silicon monoxide

$>747$ Antifoam

$>$ Dolapix CE64

$>$ Disperse-Ayd W28

\subsection{EVALUATION OF CANDIDATES}

\subsubsection{Supernatant Testing}

A batch of supernatant was prepared to resemble SRAT supernatant after nitric acid addition. The solution contained 10,000 ppm nitrate and nitrite and 5,000 ppm mercury added as $\mathrm{HgO}$. For each reductant tested, twice the stoichiometric requirement for mercury reduction was 
added to the solution assuming the reductant reacted to carbon dioxide. The temperature was slowly increased and a Nonoxor II was used to monitor gas generation. The Nonoxor instrument can measure $\mathrm{NO}_{\mathrm{x}}$ concentrations from 0-2000 ppm $+/-5 \%$. In the case of $\mathrm{NO}_{\mathrm{x}}$ generation, additional reductant was added to complete nitrite reactions to determine if mercury reduction would occur after nitrite destruction. The additional amount of reductant required for nitrite destruction was calculated assuming two moles of acid per mole of nitrite. All tests were run using $50 \mathrm{~mL}$ of supernatant in $100 \mathrm{~mL}$ beakers. Hot plates with external temperature probes were used for heating. Successful mercury reduction was judged based on visual appearance of mercury beads in the beaker.

\subsubsection{Formic acid}

Formic acid was tested first as a baseline. The initial formic addition led to $\mathrm{NO}_{\mathrm{x}}$ emissions as the solution was heated to $55^{\circ} \mathrm{C}$. Approximately $1 / 4$ the formic acid required to react with nitrite was added to the beaker, which increased the rate of $\mathrm{NO}_{\mathrm{x}}$ emissions. The remainder of the formic acid for nitrite destruction increased $\mathrm{NO}_{\mathrm{x}}$ emissions significantly. Small beads of mercury were visible after $\mathrm{NO}_{\mathrm{x}}$ emissions had peaked.

An additional round of testing was performed to determine if mercury reduction could be carried out without nitrite reactions at various temperatures. The supernatant without acid was heated to 55,75 , or $95^{\circ} \mathrm{C}$. Formic acid was then added drop wise and gas generation rates monitored. At $55^{\circ} \mathrm{C}$, the reactions were all slow and the maximum NOx reading was $115 \mathrm{ppm}$, however nitrite reactions were completed before any mercury was visible in the beaker. At 75 and $95^{\circ} \mathrm{C}$, the nitrite destruction reactions were much faster but likewise occurred before the appearance of mercury beads.

\subsubsection{Glycolic Acid}

Glycolic acid did not show any evidence of reaction with the initial addition. The additional amount for nitrite destruction was added at $60^{\circ} \mathrm{C}$, which led to $\mathrm{NO}_{\mathrm{x}}$ emissions. More glycolic acid was added and heated to $85^{\circ} \mathrm{C}$ with no significant reactions noted. Mercury reduction was not apparent.

\subsubsection{Pyruvic, Malonic, and Oxalic Acid}

Pyruvic acid addition generated $\mathrm{NO}_{\mathrm{x}}$ at room temperature. The rate of gas generation increased as the solution was heated to $55^{\circ} \mathrm{C}$. The second addition imparted a light amber color to the solution. White precipitate was formed that did not disappear when the solution was heated to $85^{\circ} \mathrm{C}$. Malonic acid behaved similarly to pyruvic acid regarding approximate reaction rates and solids formation, but the solution remained clear. Neither acid reduced mercury. Oxalic acid also showed the same type of behavior. Because mercury oxalate is a shock sensitive compound, potassium permanganate was added to the solution prior to disposal.

\subsubsection{Citric and Propionic Acid}


Citric and propionic acid reacted very slowly with nitrite as evidenced by small $\mathrm{NO}_{\mathrm{x}}$ readings and showed no mercury reduction.

\subsubsection{Glyoxylic Acid}

Glyoxylic acid formed a very fine brown precipitate that completely coated the inside of the beaker and the stir bar but no mercury beads were visible.

\subsubsection{Acrylic Acid}

Acrylic acid generated some $\mathrm{NO}_{\mathrm{x}}$ at room temperature and showed increasing reaction rates with increasing temperature. After gas generation peaked, mercury beads were noted in the beaker.

\subsubsection{Stannous Chloride and Silicon Monoxide}

Stannous chloride reacted very quickly with nitrite. Further additions formed some black solids that turned white with time. The sample was centrifuged at the end of the test, but no mercury beads were found. $\mathrm{SiO}$ reacted to form a large amount of brown solids but no mercury beads were evident.

\subsubsection{Supernate Testing Summary}

The results of the supernatant testing are summarized in Table 3.

Table 3. Supernatant Testing Results Summary

\begin{tabular}{|c|c|c|c|}
\hline Reductant & Nitrite reactions & Elemental Hg & Other solids \\
\hline Formic & Yes & Yes & No \\
\hline Glycolic & Yes & No & No \\
\hline Pyruvic & Yes & No & Yes \\
\hline Malonic & Yes & No & Yes \\
\hline Oxalic & Yes & No & Yes \\
\hline Citric & Yes & No & No \\
\hline Propionic & Yes & No & No \\
\hline Glyoxylic & Yes & No & Yes \\
\hline Acrylic & Yes & Yes & No \\
\hline $\mathrm{SnCl}_{2}$ & Yes & No & Yes \\
\hline $\mathrm{SiO}$ & Yes & No & Yes \\
\hline
\end{tabular}

The only alternative that successfully reduced mercury in the supernatant system was acrylic acid; however, there are materials handling issues that would make implementing an acrylic acid flowsheet problematic. Acrylic acid must be stored between 15 and $25^{\circ} \mathrm{C}$ to prevent violent self-polymerization. Significant controls would have to be implemented on the cold feed system to use acrylic acid at the DWPF. 


\subsubsection{High Throughput SRAT Testing}

Since a "better than" formic acid replacement was not identified in the supernatant testing, a series of small-scale runs was completed using varying formic/nitric ratios in an attempt to find the minimum required formic addition for mercury reduction. Additionally, a REDOX balanced minimum formic acid test was completed using glycolic acid in addition to formic and nitric acids. Though glycolic acid did not appear to work as a reductant for mercury in supernatant testing, its effectiveness as a formic acid replacement with regard to feed rheology, REDOX control and gas generation has been previously documented [Goles, Seymour] In addition to the minimum formic acid series of tests, a simulation was performed using the only promising alternative reductant from the supernatant screening test, acrylic acid.

The small-scale SRAT apparatus was used in these runs only for the purposes of identifying any major process issues and checking for mercury reduction. Process data such as temperature, $\mathrm{pH}$ and, in most cases, off-gas composition were not recorded. Acids were added at approximately twice the prototypical rate and the reflux period after dewatering was shortened in order to be able to complete a series of tests in one day. These tests are not prototypical, but provide a quick way to assess feasibility of flowsheet changes.

\subsubsection{Minimum Formic Acid}

The minimum formic acid series of small-scale tests were done with 20, 40, 60, and 80\% of the acid added on a molar basis as formic acid. For the purpose of comparison, the current DWPF flowsheet calls for approximately $90 \%$ of the acid blend in the SRAT to be formic to balance REDOX. An earlier $4 \mathrm{~L}$ test run targeting a stoichiometric minimum for mercury reduction ended up with $4 \%$ of the acid being formic. There was successful elemental mercury removal in all four small-scale tests, but not in the earlier $4 \mathrm{~L}$ test. While these tests showed mercury reduction is possible with less formic acid than is used in the current flowsheet, the SRAT products will be oxidizing. A method for melter REDOX control would have to be developed.

\subsubsection{Glycolic / Formic Acid Blend}

To perform the REDOX balanced minimum formic acid test, glycolic and formic acids were blended on an 80:20 molar basis and added in the same fashion as formic acid alone is normally added. The formic acid makes up $13 \%$ of the total acid mix in this REDOX balanced system. Elemental mercury was successfully steam stripped during this test.

\subsubsection{Acrylic Acid}

The acrylic acid flowsheet was investigated in a single small-scale test as above. Acrylic acid is required to be only about $40 \%$ of the acid blend to balance REDOX as it is a more effective theoretical reductant than formic acid. A gas chromatograph was used for this test. 
No hydrogen was detected and mercury was reduced. Despite these promising results, the materials handling issues with acrylic acid as discussed above would make implementation problematic.

\subsubsection{Summary of HTE SRAT Testing}

A summary of the seven SRAT simulations with their acid compositions (by mass) is presented below in Table 4.

Table 4. SRAT Testing Results Summary

\begin{tabular}{|c|c|c|c|c|c|c|}
\hline \multicolumn{4}{|c|}{ \% of Acid Added } & \multirow{2}{*}{ Elemental Hg } & \multirow{2}{*}{ Scale } & \multirow{2}{*}{ REDOX balanced } \\
\cline { 1 - 4 } Formic & Nitric & Acrylic & Glycolic & & & \\
\hline 4 & 96 & 0 & 0 & No & $4 \mathrm{~L}$ & No \\
\hline 20 & 80 & 0 & 0 & Yes & $0.5 \mathrm{~L}$ & No \\
\hline 40 & 60 & 0 & 0 & Yes & $0.5 \mathrm{~L}$ & No \\
\hline 60 & 40 & 0 & 0 & Yes & $0.5 \mathrm{~L}$ & No \\
\hline 80 & 20 & 0 & 0 & Yes & $0.5 \mathrm{~L}$ & No \\
\hline 0 & 59 & 41 & 0 & Yes & $0.5 \mathrm{~L}$ & Yes \\
\hline 13 & 44 & 0 & 43 & Yes & $0.5 \mathrm{~L}$ & Yes \\
\hline
\end{tabular}




\subsection{CONCLUSIONS}

The reductants shown below were selected for testing during the evaluation of alternative reductants for SRAT processing. The reductants fall into two general categories: reducing acids and non-acidic reducing agents. Reducing acids were selected as direct replacements for formic acid to reduce mercury in the SRAT, to acidify the sludge, and to balance the melter REDOX. Non-acidic reductants were selected as melter reductants and would not be able to reduce mercury in the SRAT. Sugar was not tested during this scoping evaluation as previous work has already been conducted on the use of sugar with DWPF feeds.

\section{Reducing Acids \\ $>$ Glycolic acid \\ $>$ Pyruvic acid \\ $>$ Malonic acid \\ $>$ Citric acid \\ $>$ Acrylic acid \\ $>$ Oxalic acid \\ $>$ Proprionic acid}

Non-acid Reducing Agents

$>$ Tin chloride

$>$ Silicon monoxide

$>747$ Antifoam

$>$ Dolapix CE64

$>$ Disperse-Ayd W28

The supernate testing indicated that acrylic acid was the only alternative reductant tested capable of reducing mercury during the SRAT cycle. Material handling issues with acrylic acid make implementation undesirable.

Based on the testing performed, the only viable short-term path to mitigating hydrogen generation in the $\mathrm{CPC}$ is replacement of formic acid with a mixture of glycolic and formic acids. An experiment using glycolic acid blended with formic on an 80:20 molar basis was able to reduce mercury, while also targeting a predicted REDuction/OXidation (REDOX) of 0.2 expressed as $\mathrm{Fe}^{2+} / \Sigma \mathrm{Fe}$. Based on this result, SRNL recommends performing a complete CPC demonstration of the glycolic/formic acid flowsheet followed by a design basis development. Of the options tested recently and in the past, nitric/glycolic/formic blended acids has the potential for near term implementation in the existing $\mathrm{CPC}$ equipment providing rapid throughput improvement.

Use of a non-acidic reductant is recommended only if the processing constraints to remove mercury and acidify the sludge acidification are eliminated. The non-acidic reductants (e.g. sugar) will not reduce mercury during CPC processing and sludge acidification would require large amounts of nitric acid (and subsequently larger reductant additions) unless a reducing acid is also used. 


\subsection{FUTURE WORK}

To pursue replacement of formic acid with a glycolic/formic blend, the first requirement is a proof of concept through a complete SRAT/Slurry Mix Evaporator (SME) cycle using nonradioactive simulants. An 80:20 blend was successful in feasibility testing; SRNL recommends performing $4 \mathrm{~L}$ SRAT/SME testing with 90:10, 80:20, and 100:0 blends. These SME products will be tested for mercury, solids, anions, elemental analysis, rheology and glass redox. This testing can be completed in a relatively short period, approximately two months. If this work is successful, a design basis development must be completed prior to implementation. This would include a radioactive demonstration in the SRNL Shielded Cells facility to ensure that actual rheology adjustment and hydrogen generation is verified as well as an assessment of melter flammability. The nitric/glycolic/formic acid blend has the greatest potential for near-term implementation of all the options evaluated to date since no equipment modifications are expected. 


\subsection{REFERENCES}

Goles, R. W., J. A. Del Debbio, R. J. Kirkham, B. D. MacIsaac, J. A. McCray, D. D. Siemer, N. R. Soelberg, Test Summary Report INEEL Sodium-Bearing Waste Vitrification

Demonstration RSM-01-2, Pacific Northwest National Laboratory, Richland, WA, 2002.

Holtzscheiter, E. W. Technical Task Request - Slurry Receipt and Adjustment Tank (SRAT) Alternative Reductant Assessment, HLW-DWPF-TTR-2008-0039, Washington Savannah River Company, Aiken, SC, 2008.

Josephs, J. E. and Stone, M. E, Melt Rate Improvement for DWPF MB3: Sugar Addition Test, WSRC-TR-2001-00158, Washington Savannah River Company, March, 2001.

Marinik, A. R., Stone, M. E., and Marsh, D. M., Rheological Modifier Testing with DWPF Process Slurries, WSRC-TR-2004-00082, Washington Savannah River Company, February, 2004.

Perry, K. J., Kimmitt, P. R., Soelberg, N. R., Tillotson, R. D., Olson, A. N., Test Results from SBW-FY01-PS-01 Vitrification Demonstration of Sodium Bearing Waste Simulant using WM-180 Surrogate, INEEL/EXT-01-01073, August, 2001.

Pickenheim, B. R., Slurry Receipt and Adjustment Tank (SRAT) Alternative Reductant Assessment, SRNS-RP-2008-00218, Savannah River Nuclear Solutions, October 2008.

Plodinec, M. J., Report of the Hydrogen Generation Review Panel - Review of Hydrogen Generation in the DWPF Washington Savannah River Company, March, 2007.

Seymour, R. G., Evaluation of Alternative Chemical Additives for High-Level Waste Vitrification Feed Preparation Processing, WHC-SD-WM-SP-009, May 1995.

Smith, M. E. Technical Evaluation of the AREVA 650MM Cold Crucible Induction Melter (CCIM) Demonstrations with Simulated Sludge Batch 3 Feed, WSRC-TR-2007-00486, December 2007.

Smith, P.A, Vienna, J. D., and Hrma P, The effects of melting reactions on laboratory-scale waste vitrification, Journal of Material Science, Volume 10, No. 8, August 1995.

Stone, M. E. and Lambert, D. P., DWPF Macrobatch 2 Melt Rate Tests, WSRC-TR-200000395, Washington Savannah River Company, October, 2000

Technical Data Summary for the Defense Waste Processing Facility: Sludge Plant, DPSTD80-38-2 
SRNL-STI-2009-00120, REVISION 0

Zamecnik, J. R. and Choi, A. S., Modeling the Impact of Elevated Mercury in Defense Waste Processing Facility Melter Feed on the Melter Off-Gas System - Preliminary Report, SRNLSTI-2009-00149, Savannah River Nuclear Solutions, March 2009. 


\section{APPENDIX A. OPTIONS FOR ELIMINATION OF FORMIC ACID}

\section{Option 1. Elimination of sludge acidification}

This option simplifies the DWPF flowsheet tremendously as the only pretreatment steps would be the addition of salt streams, glass former additions (frit), and concentration to desired solids targets. Testing with simulants during the international Cold Crucible Induction-heated Melter (CCIM) programs has indicated that caustic melter feed could be prepared with a solids loading of $45 \mathrm{wt} \%$ at waste loadings as high as 50\% [Smith, 2007]. These studies were conducted with simulants, therefore the solids loadings that could be achieved with real waste would still need to be verified. For joule-heated melter processing, the glass REDOX would be controlled by the addition of a nonacidic alternative reductant, such as sugar or other suitable reductant. Mercury removal would not occur during pretreatment, therefore elevated levels of mercury would be delivered to the melter.

The first issue with implementation of this option would be the impact of the increased mercury emissions from the melter. Testing is needed to ensure that the melter offgas system can operate at the elevated mercury levels. Modeling has been conducted to estimate what mercury species would be expected to form in the system, this work has been documented in a separate report [Zamecnik, 2009].

Another issue this option presents is the potential for gel formation in caustic slurries containing frit, especially during caustic boiling of slurries. The increased yield stress could cause issues with feeding the melter using the current feed system and could prevent adequate spreading of the cold cap. During the CCIM testing, the sludge was concentrated to approximately $38 \%$ total solids prior to a dry frit addition. No boiling was conducted with frit in the caustic slurry, but issues with gelling were noted in feed that was not used immediately. This issue could be exacerbated by incorporation of the slightly acid streams from salt processing as the $\mathrm{pH}$ could be shifted into undesirable regions.

\section{Option 2. Replacement of Formic Acid with a Non-reducing Acid to Adjust Rheological Properties}

This option assumes that acidification is needed for control of the melter yield stress and to complete the necessary feed preparation chemical reactions, but that control of the glass redox is not required or is performed by a non-acidic reducing agent such as sugar. Most candidate acids (hydrofluoric, hydrochloric, sulfuric acid) contain species that are not desirable in the melter feed (i.e., F, Cl, S have very limited glass solubility limits and/or can create significant materials of corrosion issues for the melter and off gas system). Therefore only nitric acid was considered for this evaluation. The amount of nitric acid would be greatly increased by this option and the amount of nitrate in the melter feed would be 3-4X current levels. The amount of reducing agents needed would increase significantly to balance the additional nitrate with a subsequent increase in the amount of melter offgas. 
This option generates the same concerns with emissions of mercury from the melter as Option 1, but provides for acidification to control melter feed yield stress and prevent gel formation in the Slurry Mix Evaporator (SME) and Melter Feed Tank (MFT) processes.

\section{Option 3. Replacement of Formic Acid with a Reducing Acid to Balance REDOX}

This option provides for acidification of the sludge and control of melter REDOX, but mercury removal is not performed. The amount of reductant needed is significantly less than Option 2 as the amount of nitrate added is reduced by reducing the amount of nitric acid added. Since the reducing acid may not reduce mercury, the same issues with mercury emissions from the melter as Option 1 apply to this option. Impacts of a change in reductant may include changes to the offgas compositions and condensate compositions (and subsequent recycle stream to the tank farm).

\section{Option 4. Replacement of Formic Acid with a Reducing Acid that Reduces Mercury during SRAT Processing}

This option provides for a direct replacement for formic acid in the CPC process. Mercury would be removed during CPC processing and the only significant change expected in the melter feed would be the substitution of the formate ion with the ion from the acid selected. Impacts of a change in reductant may include changes to the offgas compositions and condensate compositions (and subsequent recycle stream to the tank farm).

\section{Option 5: Minimum Formic Acid}

The four options outlined above would eliminate formic acid use during the DWPF pretreatment process, but a final option was evaluated that would minimize rather than eliminate use of formic acid. Identification of a suitable candidate to replace formic acid and perform all three roles (acidification, mercury reduction, and melter feed reductant) may not be feasible. The expert panel convened after the first Shielded Cells qualification test for Sludge Batch 4 (SB4) failed the SME hydrogen limit recommended that alternatives to formic acid be evaluated for selected roles (such as melter reductant) to minimize the amount of formic acid utilized [Plodinec, 2007]. In order to reduce the amount of formic acid used, this option would utilize formic acid only to provide for mercury reduction.

The alternative reducing acids were evaluated as replacements for the other two roles (acidification and melter reductant). Use of a non-acidic reductant for melter redox control could be considered, but it should be noted that much larger reductant additions are required and increased melter offgas would result if a non-acidic reductant is used (as discussed in Options 2 and 3). The larger additions would be required to offset the higher levels of oxidant added by the larger nitric acid addition.

This option minimizes the amount of hydrogen generation from formic acid while still retaining the current processing objectives in the CPC. Like Option 4, the primary impact of this option will be the replacement of formate ion with the ion from the acid selected if an acidic reductant is utilized. Impacts of a change in reductant may include changes to the 
offgas compositions and condensate compositions (and subsequent recycle stream to the tank farm). Tests were conducted at SRNL to determine the minimum amount of formic acid required to reduce mercury during the SRAT cycle as discussed below.

\section{Ranking of Options}

When reviewing the list of options, the one option that consistently stands out as least desirable is Option 2. If acidification of the sludge remains in the flowsheet, a balance of reducing and oxidizing acids has significant advantages over the nitric only flowsheet in terms of amount of reductant utilized and amount of offgas from the melter. SRNL does not recommend pursuing Option 2. For this same reason, use of a non-acidic reductant is not recommended as part of the minimum formic acid option.

When ranking Option 1 versus Option 3, it is assumed that rheological properties of the feed can be adjusted with appropriate modifiers. Given the only driver to add acid without mercury removal is yield stress (assuming that nitrite destruction is not required if formic acid is removed from the system), Option 3 ranks below Option 1.

In terms of ease of implementation, Options 4 and 5 rank much higher than Option 1. For example, implementation of a 80/20 blend of glycolic and formic acids in place of formic acid could utilize existing tanks and transfer lines while significant modifications to the melter offgas system may be required to eliminate the current requirement for mercury removal. These options should be explored for near term implementation while the evaluation of mercury removal and caustic processing for Option 1 are in progress. It is assumed that all options mitigate hydrogen generation and minimize formic acid while changing the CPC offgas; these items are not listed. Table A- 1 lists the options and the rankings assigned.

Table A- 1. Ranking of Alternative Reductant Options

\begin{tabular}{|l|l|l|l|}
\hline Option & Pros & Cons & Ranking \\
\hline $\begin{array}{l}\text { Option 1. Caustic processing, } \\
\text { non-acidic reductant }\end{array}$ & $\begin{array}{l}\text { Pretreatment } \\
\text { process simplified }\end{array}$ & $\begin{array}{l}\text { Mercury emissions from } \\
\text { melter significantly increased } \\
\text { Potential for gel formation or } \\
\text { rheological issues in melter } \\
\text { feed }\end{array}$ & 3 \\
\hline $\begin{array}{l}\text { Option 2. Nitric acid flowsheet, } \\
\text { non-acidic reducing agent }\end{array}$ & $\begin{array}{l}\text { Potential for gel } \\
\text { formation or } \\
\text { rheological issues } \\
\text { in melter feed } \\
\text { versus Option 1 }\end{array}$ & $\begin{array}{l}\text { Mercury emissions from } \\
\text { melter significantly increased } \\
\text { Increased melter offgas versus } \\
\text { Option 1. }\end{array}$ & 5 \\
\hline $\begin{array}{l}\text { Option 3. Reducing acid, no } \\
\text { mercury removal }\end{array}$ & $\begin{array}{l}\text { Reduced } \\
\text { emissions versus } \\
\text { Option 2. }\end{array}$ & $\begin{array}{l}\text { Mercury emissions from } \\
\text { melter significantly increased }\end{array}$ & 4 \\
\hline $\begin{array}{l}\text { Option 4. Direct replacement of } \\
\text { formic acid }\end{array}$ & $\begin{array}{l}\text { Mercury removal } \\
\text { in CPC process }\end{array}$ & $\begin{array}{l}\text { No reduction of CPC process } \\
\text { time }\end{array}$ & 1 \\
\hline
\end{tabular}


SRNL-STI-2009-00120, REVISION 0

\begin{tabular}{|l|l|l|l|}
\hline $\begin{array}{l}\text { Option 5. Reducing acid } \\
\text { combined with formic acid for } \\
\text { mercury removal }\end{array}$ & $\begin{array}{l}\text { Mercury removal } \\
\text { in CPC process }\end{array}$ & $\begin{array}{l}\text { Formic acid not completely } \\
\text { eliminated } \\
\text { No reduction of CPC process } \\
\text { time }\end{array}$ & 2 \\
\hline
\end{tabular}




\section{Distribution:}

S. L. Marra, 773-A

A. B. Barnes, 999-W

D. A. Crowley, 773-43A

S. D. Fink, 773-A

C. W. Gardner, 773-A

B. J. Giddings, 786-5A

C. C. Herman, 999-W

F. M. Pennebaker, 773-42A

J. E. Occhipinti, 704-S

D. C. Sherburne, 704-S

R. T. McNew, 704-27S

J. F. Iaukea, 704-30S

J. W. Ray, 704-S

C. J. Bannochie, 773-42A

D. J. McCabe, 773-42A

D. K. Peeler, 999-W

M. E. Stone, 999-W

J. P. Vaughan, 773-41A

M. A. Broome, 704-29S

R. N. Hinds, 704-S

J. M. Bricker, 704-27S

T. L. Fellinger, 704-26S

E. W. Holtzscheiter, 704-15S

N. E. Bibler, 773-A

A. Y. Billings, 999-W

D. R. Best, 999-W

A. S. Choi, 773-42A

R. E. Eilbling, 999-W

A. I. Fernandez, 999-W

K. M. Fox, 999W

C. M. Jantzen, 773-A

D. C. Koopman, 999-W

D. P. Lambert, 999-W

J. D. Newell, 999-W

J. M. Pariezs, 773-A

F. C. Raszewski, 999-W

S. H. Reboul, 773-A

J. R. Zamecnik, 999-W 